\title{
Teachers' TPACK Development: A Review of Literature
}

\author{
Wei Zhang 1 , Junhong Tang 2 \\ ${ }^{1}$ Educational Administration Department, Baoding Technical College of Electric Power, Baoding, China \\ ${ }^{2}$ College of Foreign Language Education and International Business, Baoding University, Baoding, China \\ Email: jessytang99@163.com
}

How to cite this paper: Zhang, W., \& Tang, J. H. (2021). Teachers' TPACK Development: A Review of Literature. Open Journal of Social Sciences, 9, 367-380. https://doi.org/10.4236/jss.2021.97027

Received: July 7, 2021

Accepted: July 23, 2021

Published: July 26, 2021

Copyright (c) 2021 by author(s) and Scientific Research Publishing Inc. This work is licensed under the Creative Commons Attribution International License (CC BY 4.0).

http://creativecommons.org/licenses/by/4.0/

\section{(c) (i) Open Access}

\begin{abstract}
The TPACK framework describes the kinds of knowledge required by teachers for successful integration of technology in teaching. TPACK is the heart of good teaching and describes the kinds of knowledge needed by a teacher for effective technology integration. In this study, such teachers' TPACK development strategies as Learning by Design Approach, Lesson Study, Microteaching, microteaching lesson study are analyzed after an analysis of the process of TPACK formation and its components. In addition, TPACK development models like SQD-model, TPACK-COPR, TPACK-IDDIRR and TPACK-COIR are also reviewed in this study. At last, further study on subject-dependent TPACK development in a comparatively large scale is put forward.
\end{abstract}

\section{Keywords}

TPACK, Learning by Design, MLS, Development Models

\section{Introduction}

The TPACK framework has had a strong influence on research and practice in teacher education and professional development and inspired extensive research and scholarship. Since 2009 there have been over 1200 journal articles and book chapters, over 315 dissertations and 28 books with TPACK as the central construct (Harris \& Wildman, 2019). The TPACK (or Technological Pedagogical Content Knowledge) framework describes the kinds of knowledge required by teachers for successful integration of technology in teaching (Mishra, 2019: p. 76). In this study, such TPACK development approaches and models as Learning by Design Approach, Lesson Study, Microteaching, Microteaching Lesson Study (MLS), SQD-model (Synthesis of Qualitative Evidence) (Tondeur, van 
Braak, Sang, Voogt, Fisser \& Leftwich, 2012), TPACK-COPR (Comprehension TPACK, Observation of instruction, Practice of instruction, and Reflection) (Niess, Ronau, Shafer, Driskell, Harper, Johnston, Browning, Koca, \& Kersaint, 2009) TPACK-IDDIRR (Introduce, Demonstrate, Develop, Implement, Reflect, and Revise) (Lee \& Kim, 2014), and TPACK-COIR (Comprehension, Observation, Instruction and Reflection) (Jang, 2010) are reviewed and analyzed in order to offer some references for researchers and educators to develop teachers' TPACK efficiently.

\section{TPACK Formation}

Early in 2001, Pierson began to use the concept of TPCK. Pierson's TPCK referred to "Technology assisting PCK". It was a multifaceted set of knowledge and skills required by a teacher to teach a specific subject for a specific grade. In 2005, Niess negated Pierson's definition of TPCK and suggested that TPCK was not only a kind of knowledge and skill but also a kind of dynamic knowledge including developing subject knowledge, technology knowledge and teaching and learning knowledge and a kind of creative thinking on how technology supported teaching and learning. Niess changed TPCK from a static concept to a dynamic one (Xu, Liu, Wang, \& Zhang, 2013). At the same year, Koehler and Mishra also put forward the concept of TPCK (Koehler \& Mishra, 2005b) on the basis of Shulman's PCK (Shulman, 1986, 1987). In 2006, Koehler and Mishra introduced TPCK in detail in the published article "Technological Pedagogical Content Knowledge: A Framework for Teacher Knowledge" (Mishra \& Koehler, 2006). Technology knowledge began to be clearly listed as teachers' knowledge and TPCK was regarded as the conceptual framework of teachers' knowledge structure.

Thompson and Mishra (2007) changed TPCK into TPACK. The new name, TPACK, doesn't just mean adding a vowel " $A$ " to make it easier to pronounce. Its deeper implication is to emphasize the necessity of three kinds of knowledge, content knowledge, pedagogical knowledge and technology knowledge, to form a whole through interaction. In other words, TPACK also means Total PACKage.

In 2008, contexts were introduced into TPACK as the eighth element. So far, TPACK framework contains three core elements, content knowledge (CK), pedagogical knowledge (PK) and technology knowledge (TK), four interacted knowledge, pedagogical content knowledge (PCK), technological content knowledge (TCK), technological pedagogical knowledge (TPK) and technological pedagogical content knowledge (TPACK), and context (Koehler \& Mishra, 2008), which can be shown in Figure 1.

Specifically, three major knowledge components form the foundation of the TPACK framework and four components in the TPACK framework address how these three bodies of knowledge interact, constrain, and afford each other as follows (Koehler, Mishra, Kereluik, Shin, \& Graham, 2014): 


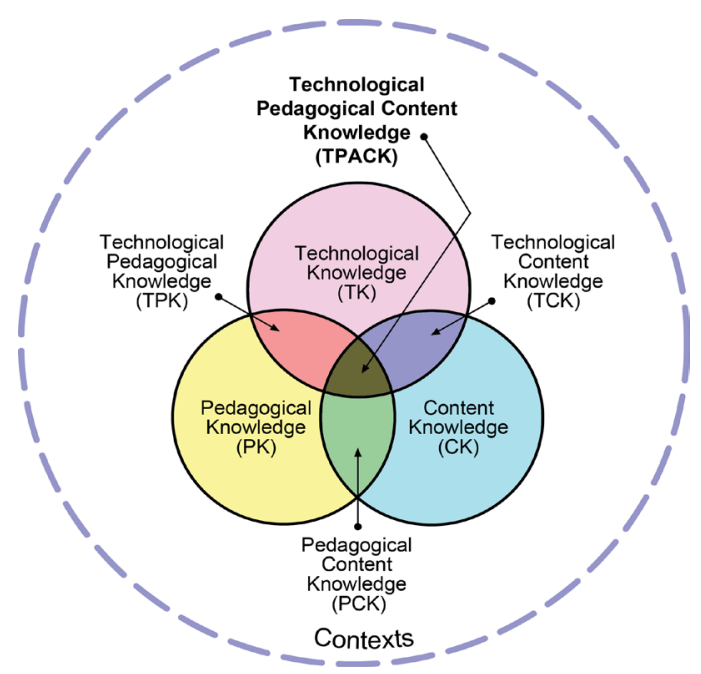

Figure 1. Technological pedagogical content knowledge. The source of the image is attributed as http://tpack.org/.

- CK refers to any subject-matter knowledge that a teacher is responsible for teaching.

- PK refers to teacher knowledge about a variety of instructional practices, strategies, and methods to promote students' learning.

- TK refers to teacher knowledge about traditional and new technologies that can be integrated into curriculum.

- TCK refers to knowledge of the reciprocal relationship between technology and content. Disciplinary knowledge is often defined and constrained by technologies and their representational and functional capabilities.

- PCK is to Shulman's (1986) notion of "an understanding of how particular topics, problems, or issues are organized, represented, and adapted to the diverse interests and abilities of learners, and presented for instruction" (p. 8).

- TCK refers to an understanding of technology can constrain and afford specific pedagogical practices.

- TPACK refers to knowledge about the complex relations among technology, pedagogy, and content that enable teachers to develop appropriate and context-specific teaching strategies.

Mishra (2019) renamed the outer dotted circle "Contextual Knowledge (XK)" (i.e., the teacher's knowledge of the context) which was originally labeled as "Contexts". XK for "conteXtual Knowledge" distinguishes it from CK. Using X for conteXtual could be appropriate because $\mathrm{X}$ usually denotes a variable, and contextual knowledge often is highly variable. Figure 2 shows the revised version of the TPACK diagram. The addition of XK to the diagram has another benefit. It highlights the organizational and situational constraints that teachers work within. The success of their efforts depends not as much on their knowledge of T, P, C and its overlaps, but rather on their knowledge of the context (Mishra, 2019: p. 77).

So far, a brief history of TPACK is shown in Table 1. 


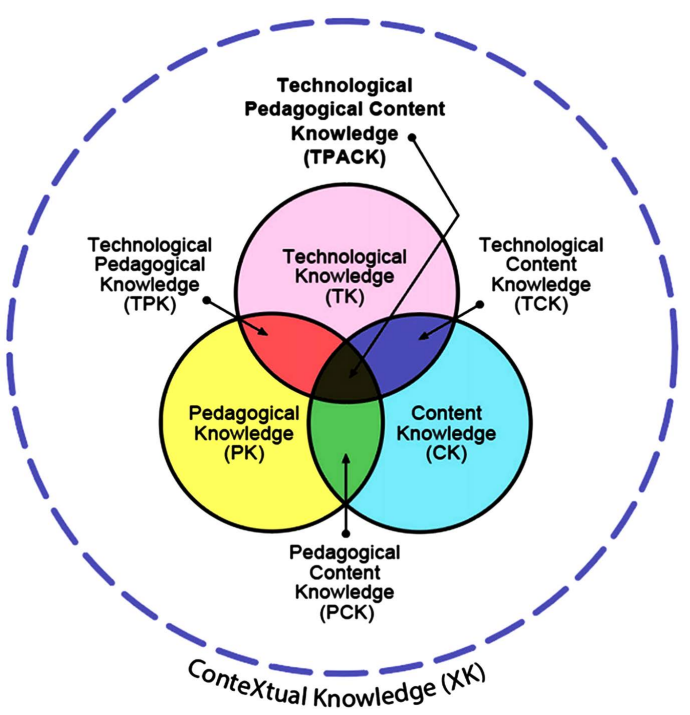

Figure 2. Revised version of the TPACK image. The source is from Mishra Punya (2019). Considering Contextual Knowledge: The TPACK Diagram Gets an Upgrade, Journal of Digital Learning in Teacher Education.

Table 1. A brief history of TPACK development.

\begin{tabular}{l}
\hline 1986 Shulman says pedagogy and content knowledge (PCK) must be considered together. \\
2001 Pierson began to use the concept of TPCK to refer to "Technology assisting PCK". \\
$\begin{array}{l}\text { Niess suggested TPCK was not only a kind of knowledge and skill but also a kind of } \\
\text { dynamic knowledge including developing subject knowledge, technology knowledge } \\
\text { and teaching and learning knowledge and it is a kind of creative thinking on how } \\
\text { technology supported teaching and learning. }\end{array}$ \\
2005 Koehler and Mishra also put forward the concept of TPCK. \\
Koehler and Mishra introduced TPCK in detail in the published article "Technological \\
Pedagogical Content Knowledge: A Framework for Teacher Knowledge" (Mishra \& \\
Koehler, 2006). Technology knowledge began to be clearly listed as teachers' knowledge \\
and TPCK was regarded as the conceptual framework of teachers' knowledge structure. \\
Thompson and Mishra changed TPCK into TPACK. \\
Koehler and Mishra introduced contexts into TPACK as the eighth element. So far, \\
TPACK framework contains three core elements, CK, PK and TK, four interacted \\
knowledge, PCK, TPK, TCK, TPACK, and contexts. \\
Mishra renamed the outer dotted circle "Contextual Knowledge (XK)" \\
(i.e., the teacher's knowledge of the context) which was originally labeled as "Contexts".
\end{tabular}

\section{TPACK Development}

In this part, such TPACK development approaches and models as Learning by Design Approach, Lesson Study, Microteaching, MLS, SQD-model, TPACK-COPR, TPACK-IDDIRR and TPACK-COIR are reviewed.

\subsection{Learning by Design Approach}

Learning by Design Approach (LDA) offers the idea of developing TPACK by collaborative design to solve real teaching and learning problems, though it lacks 
specific scaffolds and concrete illustrations.

Learning by Design approach is to develop TPACK by teachers' working in teams to design solutions to ill-structured, real world problems of teaching and learning over an extended period of time. Instead of directly teaching technologies to teachers, teachers' learning is driven by the design-problem and a consideration of different technologies that may contribute to the final design solution. Because real problems of practice require designers to integrate content, pedagogy, and technology, learners necessarily engage with actively integrating these types of knowledge as they work on a solution (Koehler et al., 2014: p. 108). Koehler and Mishra (2005a) reported three course examples that all used the Learning by Design approach to help teachers learn about educational technology and develop their TPCK. Koehler and Mishra (2005b) reported "learning by design course" approach which promote student- and faculty-participants' growth of TPCK. All the participants (4 faculty members and 14 masters students) worked collaboratively on designing an online course. They engage in inquiry, research and design, in collaborative groups to design tangible, meaningful artifacts (such as the website, syllabus and assignments for an online course) as end products of the learning process. Design is the anchor around which the class (and learning) happens. Koehler, Mishra and Yahya (2007) describes their efforts on developing TPCK as a group of educators participated in a design seminar where they worked collaboratively in small groups to develop technological solutions to authentic pedagogical problems, which are interested in better understanding the manner and process by which TPCK develop through participation in a design-based activity, for example, changes in the manner that groups think and talk about technology throughout the design process.

Zhan, Quan and Ren (2013) made an empirical study in a normal university in Shanghai, China, to investigate how to improve preservice mathematics teachers' TPACK level by learning-by-design micro-course. Durdu and Dag (2017) designed and implemented a computer based mathematics course based on a TPACK framework to examine preservice teachers' TPACK development. Others also have explicitly used design as a vehicle for helping teachers to develop TPACK (Koehler et al., 2014: p. 108).

\subsection{TPACK Development Models}

In order to develop teachers' TPACK, researchers have made some efforts in trying building such models as TPACK-COIR, TPACK-COPR and TPACK-IDDIRR with specific scaffolds in learning by design. SQD-Model put forward six key themes of preparing preservice teachers to integrate technology into their lessons.

Lee and Kim (2014) developed the TPACK-IDDIRR (Introduce, Demonstrate, Develop, Implement, Reflect, and Revise) Model for preservice teachers learning of TPACK, which is shown in Figure 3, and investigated its effects in a technology integration course with fifteen participants from diverse majors. 
Through analysis of the 15 participants' written materials and TPACK survey responses, group lesson plans, and the researchers' field notes, they found that the participants had difficulties in understanding $\mathrm{PK}$, which hindered their learning of integrated knowledge of TPACK and the TPACK learning of the 15 participants was the combination rather than the integration of $\mathrm{PK}$, TK and CK.

In the TPACK-IDDIRR Model, Introduce is the first stage, which aims to help preservice teachers understand TPACK (Jang \& Chen 2010; Lee \& Kim, 2014), build TPACK knowledge base and prepare and facilitate later TPACK-based design activities (Lee \& Kim, 2014). Second, Demonstration means preservice teachers observe their instructor's demonstration of TPACK-based teaching examples aiming to enhance peservice teachers understanding of TPACK (Lee \& Kim, 2014). Although the former two stages, Introduce and Demonstration, are named in the perspective of the instructor, which aim to help peservice teaches comprehend and observe TPACK.

The former two stages, Introduce and Demonstration are carried out mainly by the instructor or instructors while the later four stages, Develop, Implement, Reflect, and Revise are carried out by preservice teachers. These stages are iterative learning activities that comprise Learning TPACK by Design as shown in Figure 3 (Lee \& Kim, 2014: p. 444). In the third stage, Develop, preservice teachers

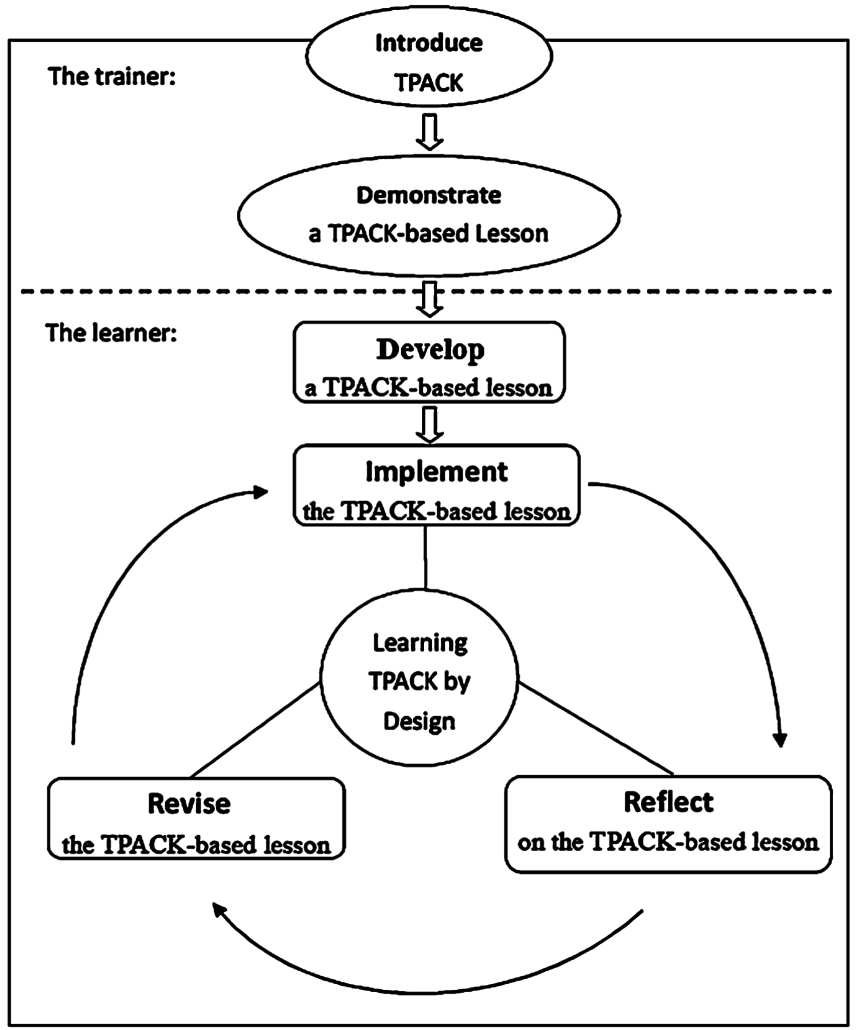

Figure 3. The TPACK-IDDIRR Model. The source is from Lee, Chia-Jung, \& Kim (2014). An implementation study of a TPACK-based instructional design model in a technology integration course. Education Tech Research Dev, 62, 437-460. 
are divided into small groups and each group develops a TPACK-based lesson plan based on what they learned in the previous two stages (Lee \& Kim, 2014: p. 444). In the fourth stage, Implement, one participant of the group teaches the lesson and the other participants act as students and provide feedback. The process of teaching is videotaped. Fifth, Reflect, refers to each group reflects and discuss the weak and strong points of the lesson after reviewing the videotape. Last, Revise, each group revises their lesson plan based on their collective reflection. Then, the next member from each group implements (I) the revised lesson and each group goes through the reflect $(\mathrm{R})$ and revise $(\mathrm{R})$ stages again.

Jang (2010) suggested an IWB-based model of TPACK-COIR (Comprehension, Observation, Instruction and Reflection) by integrating whiteboards (IWBs) technology and peer coaching to develop the TPACK of secondary science teachers in real classrooms. After analyzing the data of four in-sevice science teachers' written assignments, reflective journals and interviews, Jang (2010) found the proposed model, TPACK-COIR shown in Figure 4, can develop the TPACK of science teachers.

TPACK-COIR Model comprises four main activities: 1) Comprehension of TPACK, 2) Observation of peer instruction, 3) Instruction of a real class, and 4) Reflection of TPACK. The IWB technology was integrated to fully implement the TPACK-COIR model (Jang, 2010: p. 1746). Specifically, Comprehension of TPACK refers to study on the topics of textbooks and TPACK articles in teams.

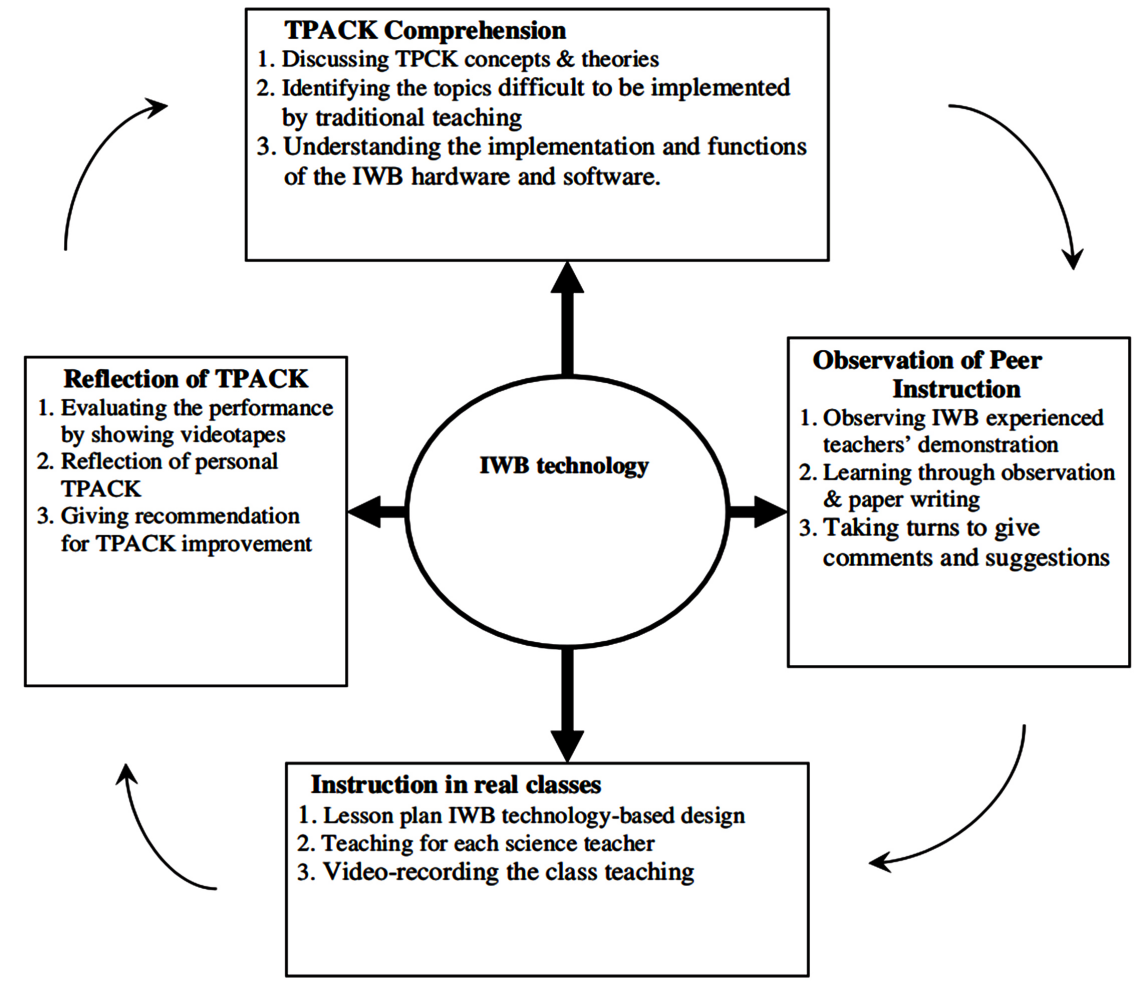

Figure 4. The TPACK-COIR model. The TPACK-COIR Modell is from Jang S. J. (2010). Integrating the interactive whiteboard and peer coaching to develop the TPACK of secondary science teachers. Computers \& Education, 55(4), 1744-1751. 
Observation of peer instruction is observation of experienced peer teachers using IWB technology. Participants should observe teaching and note skills according to the TPACK theories and strategies they have learned. More importantly, after watching the demonstration, science teachers take turns to give their comments and suggestions. In the third activity of Instruction, the science teachers make IWB technology-based lesson plan and then implement it in their classrooms. All the lessons are videotaped, too. Finally, Reflection of TPACK, each teacher should show the videotapes of his/her teaching to share his/her teaching experience with others which can stimulate teachers' self-reflection (Jang, 2010).

Jang and Chen (2010) proposed TPACK-COPR (TPACK Comprehension, Observation, Practice and Reflection) as shown in Figure 5. They examined the Impact of the model on 12 preservice science teachers' TPACK development through the analysis of such data as written assignments, online data, reflective journals, videotapes and interviews and found the TPACK-COPR Model could help preservice teachers develop technological pedagogical methods and strategies of integrating subject-matter knowledge into science lessons, and further enhanced their TPACK.

This TPACK-COPR Model also comprises four main activities. They are: 1) TPACK comprehension, which includes studying on the topics of textbook and

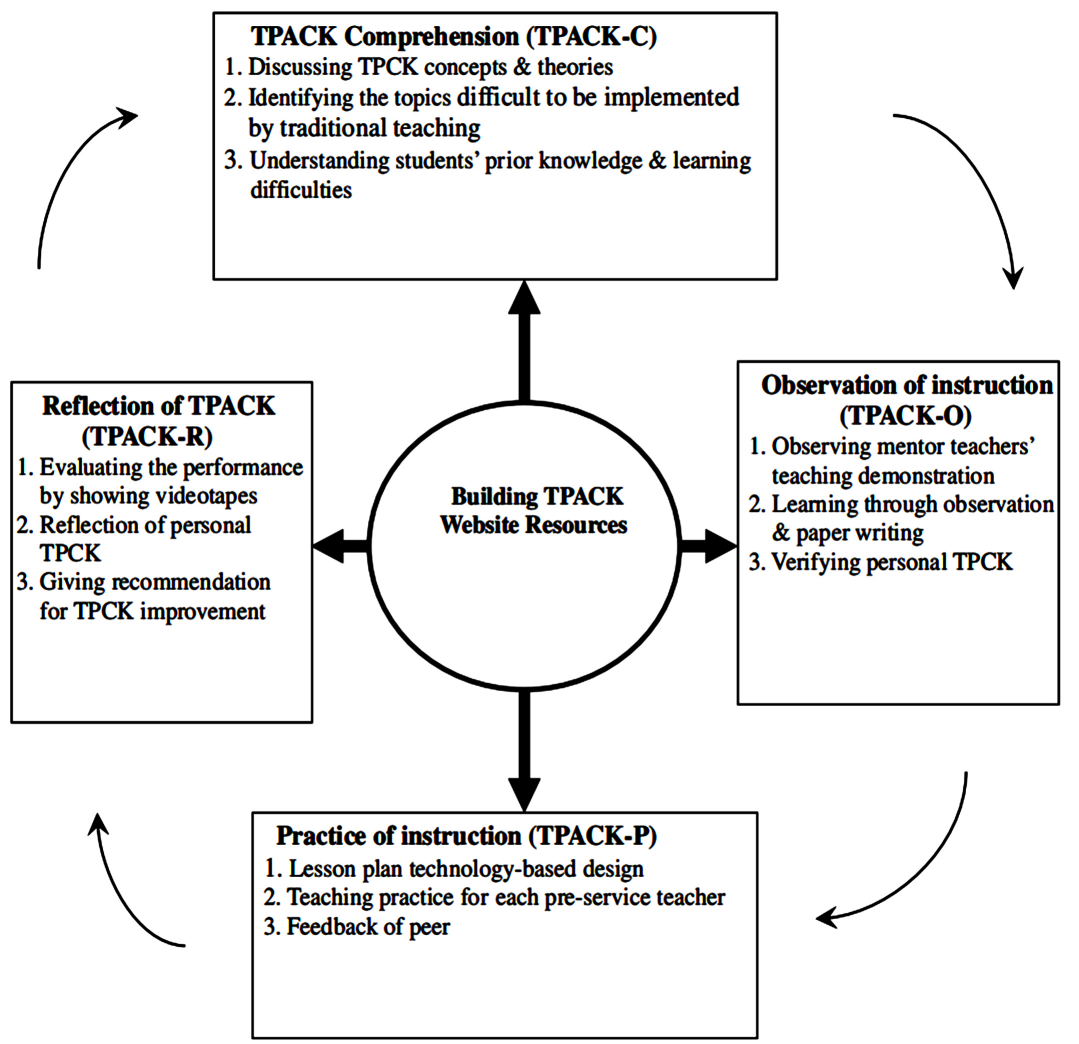

Figure 5. The TPACK-COPR model. The TPACK-COPR Model is from Jang, Syh-Jong, \& Chen, Kuan-Chung (2010). From PCK to TPACK: Developing a transformative model for preservice science teachers. Journal of Science Education and Technology, 19(6), 553-564. 
TPACK articles in teams. 2) Observation of instruction. In the second main activity, preservice teachers observe experienced mentor science teachers teaching and note their skills according to the learned TPACK theories and strategies. More importantly, preservice teachers will give their comments and suggestions on the observed teaching in turn after watching. 3) Practice of instruction. In the third activity, preservice teachers learn to design technology-based lesson plans and apply it to teaching practice. The teaching performance is also videotaped. What's more, the peer would analyze and comment on the weakness and strong points of their teaching after the practices. Finally, reflection of TPACK, each preservice teacher should show the videotapes of his/her teaching to share his/her teaching experience with others. This teaching practice can stimulate teachers' self-reflection.

On the basis of an extensive search in the Web of Science, Tondeur, van Braak, Sang, Voogt, Fisser and Leftwich (2012) put forward six key themes after synthesizing the results of 19 qualitative studies focusing on strategies to prepare preservice teachers to integrate technology into their lessons. The six key themes which are shown in Figure 6 are: 1) using teacher educators as role models, 2) reflecting on the role of technology in education, 3) learning how to use technology by design, 4) collaboration with peers, 5) scaffolding authentic technology experiences, and 6) continuous feedback.

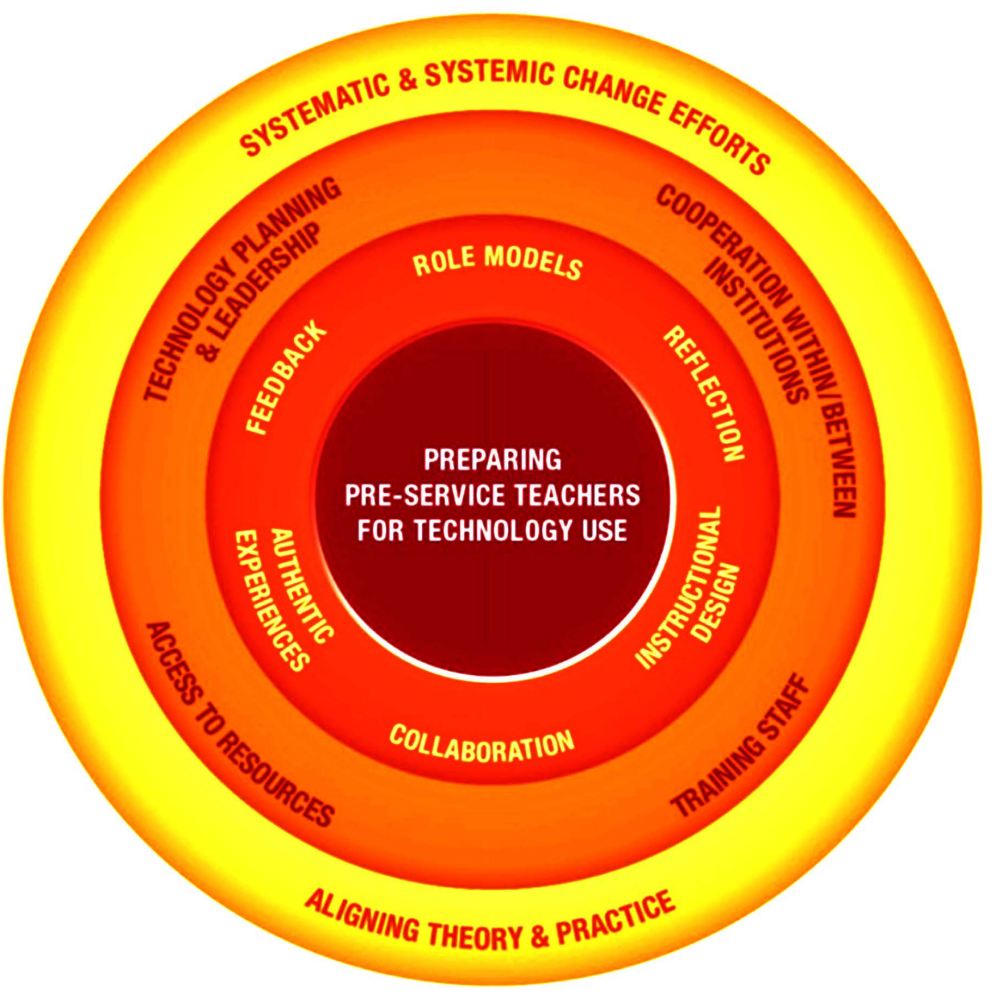

Figure 6. SQD Model to prepare preservice teachers for technology use. The SQD Model is from Tondeur et al. (2012). Preparing preservice teachers to integrate technology in education: A synthesis of qualitative evidence. Computers \& Education, 59, 134-144. 


\subsection{Lesson Study, Microteaching and Microteaching Lesson Study (MSL)}

Lesson study is a form of professional development highly valued among Japanese teachers (Fernández, 2010). The lesson study process brings a group of teachers together to collaboratively design and investigate a "research lesson" developed to meet a specified overarching student-learning goal (Fernández, 2010). It includes cycles composed of several phases: collaborative planning, lesson observation by colleagues and other knowledgeable advisers, analytic reflection, and ongoing revision (Fernández, 2010). As part of the process, lesson study groups develop a written reflective report of their work (Fernández, 2010: p. 351). Microteaching also has been shown to be an effective strategy in strengthening pedagogical skills (Fernández, 2010), but lacks the repetitive reflective process involved in the lesson study process (Cavin, 2008: pp. 29-30).

Some researchers made some efforts in the effects of Lesson Study or Microteaching on preservice teachers' TPACK development. Chew \& Lim (2013) found that the use of Geometer's Sketchpad (GSP) in teaching mathematics through Lesson Study (LS) can enhance preservice Mathematics teachers' TPACK. Danday and Monterola (2019) made an quasi-experiment in which 18 fourth year BSED Physical Science majors who were randomly assigned to either experimental or comparison group and they found Multiple-Representation Lesson Study had a positive effect on the preservice teachers TPACK by triangulated methods of researcher-made written tests, teaching observations, preservice teachers' outputs, interviews, journal entries, and field notes. Mutlu, Polat, and Alan (2019) examined the effects of micro-teaching practices on 10 preservice mathematics teachers' TPACK development and found a positive effect through a semi-experimentd by using an observation form consisting of ten questions as a data collection tool. Paristiowati, Yusmaniar, Nurhadi, and Imansari (2020) found that Lesson Study can help prospective chemistry teachers improve their TPACK capabilities by using a qualitative descriptive method of lesson plan analysis, learning observation, reflective journals, interviews and TPACK questionnaires with research according to three prospective teachers.

The combination of lesson study with microteaching is called microteaching lesson study (MLS) (Fernández, 2010). MLS is the application of microteaching through lesson study. MLS provides a context for preservice teachers to develop pedagogical content knowledge, knowledge of teaching, content, and learning, and images of reform-oriented teaching (Fernandez, 2005). MSL is effective for improving preservice teacher skills and professionalism (Murtafiah \& Lukitasari, 2019: p. 203). The process of MLS, when used in a teacher education program, typically involves the preservice teacher developing a lesson plan, and then teaching that lesson to a small group of his or her peers (Fernández, 2010: p. 353).

Some researchers have made some study on MSL which aims to develop preservice teachers' TPACK or PCK through enrolled methods courses. Cavin 
(2008) explored the development of TPACK in the participants of six preservice teachers enrolled in the required technology course for mathematics and science teacher education at a small rural college as they participated in micro-teaching lesson study (MLS). The data were collected qualitatively via audio and video recordings, observations, interviews, and course documents. Findings indicate that the preservice teachers developed an awareness of the nuances of teaching with technology in a student-centered learning environment. Kurt and Çakıroğlu (2018) examined the TPACK development of preservice mathematics teachers in statistics teaching in the context of MLS, and each MLS group consists of 5 participants. Their findings showed that preservice mathematics teachers' TPACK changed and developed through MLS. Kurt (2016) found two MLS groups (one consisted 5 members and the other 4) of 9 participants of preservice elementary mathematics teachers' TPACK changed and developed through MLS, especially in statistical content knowledge, statistical pedagogical knowledge and technological content knowledge, which is also through qualitative efforts of case study. Murtafiah and Lukitasari (2019) detected the improvement of PCK of two MLS groups (one consisted 4 members and the other 3 ) of seven preservice mathematics teacher through observation, unstructured interviews, and documentation. Kartal, Ozturk and Ekici (2012) made case study in "Special Teaching Methods-II" course and found MSL contributed a lot to preservice science teachers' PCK. Zhou, Xu and Martinovic found (2017) explored the effectiveness of using MLS approach in science methods courses to prepare teacher candidates for teaching science with technology and found that MSL in methods courses help preservice teachers to learn how to teach with technology and develop their technology related PCK. The significance of MSL lies in the opportunity of practice, collaborative refection, instant feedback, and learning from each other (Zhou, Xu, \& Martinovicfound, 2017: p. 85). Zhou and Xu (2011) have been using MSL to provide teacher candidates opportunities to learn and practice the use of technology in science teaching. The findings of Zhou, Xu and Martinovic (2017) indicates that MLS within the context of methods courses is a promising way to develop teacher candidates' TPACK knowledge and skills by analyzing 65 preservice teachers' lesson plans, reflective journals, and researchers/instructors' observation notes of microteaching performance.

According to the literature, to date, researchers have made some research on the effect of MSL, Lesson Study or Microteaching on the development of TPACK in a comparatively small group of preservice teachers who are mainly major in mathematics or science and the average number of the participants is less than 30 by means of a qualitative descriptive method of lesson plan analysis, learning observation, reflective journals, interviews or TPACK questionnaires.

\section{Summary}

Considering the above TPACK development approaches and models, the collaboration of participants is of critical importance. Although the Learning by De- 
sign Approach put forward the idea of design, it is just a general approach of learning by design without specific scaffolds which may not work for preservice teachers who may not possess sufficient expertise in teaching (Chai \& Koh, 2017). However, all the three Models of TPACK-COIR, TPACK-COPR and TPACK-IDDIRR offer specific lesson design model to scaffold the design process with these three common activities of lesson plan, teaching the lesson and videotaping the whole teaching performance, discussing and reflecting the lesson in collaborative groups, which are underpinned by MSL, though they do not mention MSL clearly.

To date, researchers have made some research on the effect of MSL on TPACK development in a comparatively small group of teachers who are mainly major in mathematics and science and the average number of the participants is less than 30 by means of a qualitative descriptive method of lesson plan analysis, learning observation, reflective journals, interviews or TPACK questionnaires. So, the future study can further investigate the effect of MSL on such subject-dependent teachers' TPACK development as in language, history, literature in a comparatively large number of participants. Moreover, reflection and collaboration play an important role in teachers' TPACK development. Researchers and educators are supposed to pay attention to it in their cultivation of teachers' TPACK.

\section{Acknowledgements}

This paper is under the project of "The Research and Practice of Blending Teaching Competence of Higher Vocational College Teachers (No. SQ192022)" supported by Humanities and Social Science Research Project of Hebei Education Department. All the project members made their contributions to the paper.

\section{Conflicts of Interest}

The authors declare no conflicts of interest regarding the publication of this paper.

\section{References}

Cavin, R. M. (2008). Developing Technological Pedagogical Content Knowledge in Preservice Teachers through Microteaching Lesson Study. A Dissertation Submitted for the Degree of Doctor of Philosophy, Department of Middle and Secondary Education in Partial Fulfillment of the Requirements.

Chai, C. S., \& Koh, J. H. L. (2017). The Scaffolded Technological Pedagogical Content Knowledge Lesson Design Model. In C. S. Chai, J. H. L. Koh, \& Y. H. Teo (Eds.), Technology-Enhanced 21st Century Learning (pp. 101-114). Pearson.

Chew, C., \& Lim, C. (2013). Developing Pre-Service Teachers' Technological Pedagogical Content Knowledge for Teaching Mathematics with the Geometer's Sketchpad through Lesson Study. Journal of Education and Learning, 2, 1-8.

https://doi.org/10.5539/jel.v2n1p1

Danday, B. A., \& Monterola, S. L. (2019). Multiple-Representation Physics Lesson Study: 
Enhancing Pre-Service Teachers' Technological Pedagogical Content Knowledge. European Journal of Education Studies, 5, 105-131.

Durdu, L., \& Dag, F. (2017). Preservice Teachers' TPACK Development and Conceptions through a TPACK-Based Course. Australian Journal of Teacher Education, 42, 150-171. https://doi.org/10.14221/ajte.2017v42n11.10

Fernández, M. (2005). Learning through Microteaching Lesson Study in Teacher Preparation. Action in Teacher Education, 26, 37-47. https://doi.org/10.1080/01626620.2005.10463341

Fernández, M. (2010). Investigating How and What Prospective Teachers Learn through Microteaching Lesson Study. Teaching and Teacher Education, 26, 351-362. https://doi.org/10.1016/j.tate.2009.09.012

Harris, J., \& Wildman, A. (2019). TPACK Newsletter, No. 39. http://bit.ly/TPACKNewslettersArchive

Jang, S. J. (2010). Integrating the Interactive Whiteboard and Peer Coaching to Develop the TPACK of Secondary Science Teachers. Computers \& Education, 55, 1744-1751. https://doi.org/10.1016/j.compedu.2010.07.020

Jang, S.-J., \& Chen, K.-C. (2010). From PCK to TPACK: Developing a Transformative Model for Preservice Science Teachers. Journal of Science Education and Technology, 19, 553-564. https://doi.org/10.1007/s10956-010-9222-y

Kartal, T., Ozturk, N., \& Ekici, G. (2012). Developing Pedagogical Content Knowledge in Preservice Science Teachers through Microteaching Lesson Study. Social and Behavioral Sciences, 46, 2753-2758. https://doi.org/10.1016/j.sbspro.2012.05.560

Koehler, M. J., Mishra, P., \& Yahya, K. (2007). Tracing the Development of Teacher Knowledge in a Design. Computers \& Education, 49, 740-762. https://doi.org/10.1016/j.compedu.2005.11.012

Koehler, M. J., \& Mishra, P. (2005a). Teachers Learning Technology by Design. Journal of Computing in Teacher Education, 21, 94-102.

Koehler, M. J., \& Mishra, P. (2005b). What Happens When Teachers Design Education Technology? The Development of Technological Pedagogical Content Knowledge. Journal of Educational Computing Research, 32, 131-152. https://doi.org/10.2190/0EW7-01WB-BKHL-QDYV

Koehler, M. J., \& Mishra, P. (2008). Introducing TPCK. In AACTE Committee on Innovation and Technology (Eds.), Handbook of Technological Pedagogical Content Knowledge (TPCK) for Educators (pp. 3-29). Routledge.

Koehler, M. J., Mishra, P., Kereluik, K., Shin, T. S., \& Graham, C. R. (2014) The Technological Pedagogical Content Knowledge Framework. In J. M. Spector et al. (Eds.), Handbook of Research on Educational Communications and Technology (pp. 101-111). Springer. https://doi.org/10.1007/978-1-4614-3185-5 9

Kurt, G. (2016). Technological Pedagogical Content Knowledge (TPACK) Development of Preservice Middle School Mathematics Teachers in Statistics Teaching: A Microteaching Lesson Study. A Dissertation submitted for the Degree of Doctor of Philosophy, Department of Elementary Education in Partial Fulfillment of the Requirements.

Kurt, G., \& Çakıroğlu, E. (2018). Preservice Mathematics Teachers’ TPACK Development in Statistics Teaching: A Microteaching Lesson Study. In M. A. Sorto, A. White, \& L. Guyot (Eds.), Looking Back, Looking Forward. International Statistical Institute.

Lee, C.-J., \& Kim, C. M. (2014). An Implementation Study of a TPACK-Based Instructional Design Model in a Technology Integration Course. Educational Technology Research and Development, 62, 437-460. https://doi.org/10.1007/s11423-014-9335-8 
Mishra, P. (2019). Considering Contextual Knowledge: The TPACK Diagram Gets an Upgrade. Journal of Digital Learning in Teacher Education, 35, 76-78. https://doi.org/10.1080/21532974.2019.1588611

Mishra, P., \& Koehler, M. J. (2006). Technological Pedagogical Content Knowledge: A Framework for Integrating Technology in Teacher Knowledge. Teachers College Record, 108, 1017-1054. https://doi.org/10.1111/j.1467-9620.2006.00684.x

Murtafiah, W., \& Lukitasari, M. (2019). Developing Pedagogical Content Knowledge of Mathematics Pre-Service Teacher through Microteaching Lesson Study. Jurnal Pendidikan Matematika, 13, 201-218. https://doi.org/10.22342/jpm.13.2.7663.201-218

Mutlu, Y., Polat, S., \& Alan, S. (2019). Development of Preservice Mathematics Teachers' TPACK through Micro Teaching: Teaching the VuStat Program. International Journal of Technology in Education and Science (IJTES), 3, 107-118.

Niess, M. L., Ronau, R. N., Shafer, K. G., Driskell, S. O., Harper S. R., Johnston, C., Browning, C., Özgün-Koca, S. A., \& Kersaint, G. (2009). Mathematics Teacher TPACK Standards and Development Model. Contemporary Issues in Technology and Teacher Education, 9, 4-24.

Paristiowati, M., Yusmaniar, Nurhadi, M. F., \& Imansari, A. (2020). Analysis of Technological Pedagogical and Content Knowledge (TPACK) of Prospective Chemistry Teachers through Lesson Study. Journal of Physics: Conference Series, 1521, Article ID: 042069. https://doi.org/10.1088/1742-6596/1521/4/042069

Shulman, L. S. (1986). Those Who Understand: Knowledge Growth in Teaching. Educational Researcher, 15, 4-14. https://doi.org/10.3102/0013189X015002004

Shulman, L. S. (1987). Knowledge and Teaching: Foundation of New Reform. Harvard: Educational Review, 57, 1-22. https://doi.org/10.17763/haer.57.1.j463w79r56455411

Thompson, A. D., \& Mishra, P. (2007). TPCK: A New Direction for Technology in Teacher Education Programs. Journal of Computing in Teacher Education, 23, 78, 104.

Tondeur, J., Braak, V. J., Sang, G. Y., Voogt, J., Fisser, P., \& Ottenbreit-Leftwich, A. (2012). Preparing Preservice Teachers to Integrate Technology in Education: A Synthesis of Qualitative Evidence. Computers \& Education, 59, 134-144. https://doi.org/10.1016/j.compedu.2011.10.009

Xu, P., Liu, Y. H., Wang, Y. N., \& Zhang, H. (2013). Reviews and Enlightenment of Foreign Measurement on Technological Pedagogical Content Knowledge. E-Education Research, 34, 98-101.

Zhan, Y., Quan, J. Q., \& Ren, Y. Q. (2013). An Empirical Study on the Technological Pedagogical Content Knowledge Development of Preservice Mathematics Teachers in China. International Journal of Social Media and Interactive Learning Environments (IJSMILE), 1, 199-212. https://doi.org/10.1504/IJSMILE.2013.053600

Zhou, G., \& Xu, J. (2011). Technology Capacity Building for Pre-Service Teachers through Methods Courses: Taking Science as Example. International Journal of Online Pedagogy and Course Design, 1, 49-61. https://doi.org/10.4018/ijopcd.2011070104

Zhou, G., Xu, J., \& Martinovic, D. (2017). Developing Pre-Service Teachers' Capacity in Teaching Science with Technology through Microteaching Lesson Study Approach. EURASIA Journal of Mathematics Science and Technology Education, 13, 85-103. https://doi.org/10.12973/eurasia.2017.00605a 